\title{
Stunting Incidence in Tegalrejo Yogyakarta
}

\author{
$1^{\text {st }}$ Ellyda Rizki Wijhati \\ Midwifery Study Program Faculty of \\ Health Science \\ University Aisyiyah Yogyakarta \\ Yogyakarta, Indonesia \\ ellyda_wijhati@unisayogya.ac.id \\ ORCID id: 0000-0002-2389-8322
}

\author{
$2^{\text {nd }}$ Rosmita Nuzuliana \\ Midwifery Study Program Faculty of \\ Health Science \\ University Aisyiyah Yogyakarta \\ Yogyakarta, Indonesia \\ rosmitanz@unisayogya.ac.id \\ ORCID id:0000-0003-1683-439
}

\author{
$3^{\text {rd }}$ Maulita Listian Eka Pratiwi \\ Midwifery Study Program Faculty of \\ Health Science \\ University Aisyiyah Yogyakarta \\ Yogyakarta, Indonesia \\ maulitasukmono@gmail.com \\ ORCID id: 0000-0001-5137-6671
}

\begin{abstract}
Stunting is a major public health problem in lowand middle-income countries because of its association with an increased risk of morbidity and death during childhood. The impact of stunting is reducing children's intelligence so that it will affect the quality of life of children in the next life. The purpose of this study is to analyze the characteristics of stunted children under five in the Tegalrejo Public Health Center in Yogyakarta. It is descriptive, explanatory research. The population of this study is all stunted children under five years old aged 24-59 months, with a total sampling method. The instruments used infatometer, height gauge, and $\mathrm{z}$ score table. The results showed that the number of stunting children was 55 children with $25(45.5 \%)$ z-scores <-3SD and $30(54.5 \%)$ children with z-scores <-2SD. The findings also revealed that the sex who experienced the most stunting was boys67.3\%), the age of the most stunted children was 24-36 months, $87.4 \%$ of respondents were given exclusive breastfeeding, $89 \%$ of the stunted children had a regular eating pattern, $60 \%$ of the respondents came from families that their income was > minimum wage of Yogyakarta City, $60 \%$ of respondents were educated mothers graduated from high school, $60 \%$ of respondents were housewives, and $60 \%$ of respondents were the first child
\end{abstract}

Keywords - Stunting, toddlers, malnutrition, short height

\section{INTRODUCTION}

One of the nutritional problem that often occurs in Indonesia is Stunting. Stunting is a chronic malnutrition problem caused by a lack of nutrition in a long time due to food that does not meet per nutritional needs. Stunting occurs when the fetus is still in the womb and only appears when the child is two years old. Malnutrition at an early age increases infant and child mortality, causes sufferers to get sick easily, and has a posture that is not optimal when they are adults[1]. Based on the Basic Health Research in 2018, the national stunting prevalence reached $30,8 \%$ [2]. This shows that around 8 million Indonesian children experience suboptimal growth. The prevalence of stunting in Indonesia is higher than in other countries in Southeast Asia, such as Myanmar (35\%), Vietnam (23\%), and Thailand (16\%). Indonesia is in the fifth rank in the world for the number of children with stunting. More than a third of children under the age of five in Indonesia are below average height.
Yogyakarta City is one of the regency-level regions in the Special Region of Yogyakarta, which has the narrowest area with densely populated areas. The prevalence of stunting in Yogyakarta City is $12.82 \%$, while the prevalence in DIY in 2018 is $13.86 \%$. Yogyakarta stunting prevalence occupies the third number after Gunungkidul and Kulon Progo [4]. Yogyakarta City has several sub-districts, one of which is Tegalrejo sub-district. The height monitoring activities in the working area of the TegalrejoPrimary Health Carehave been carried out regularly by the growth monitoring at the posyandu, but in the implementation of height measurements / lengths of the child's body is still not done properly and does not interpret the measurement results. This result is in an unidentified case of stunting. According to a research there were four factors related to the occurrence of stunting, namely birth weight, gender, a region of residence, and economic status [5].

The determinant risk factors of stunting are income, many household members, father's height, maternal height, and exclusive breastfeeding [6]. The results of the study showed that the determinant factors causing stunting were family income, maternal nutritional knowledge, maternal parenting, history of infectious disease, history of immunization, protein intake, and maternal education [7]. Students who are stunting have less learning achievement, while non-stunting students have better learning achievement. It is in light of this that the researchers sought to assess the characteristics of stunting toddlers in the Tegalrejo Public Health Center in Yogyakarta

\section{METHOD}

This research is descriptive research with crosssectional time approach. The variables in this study include gender, age of the child, mother's occupation, mother's education, socioeconomic status, weight at birth, diet, and exclusive breastfeeding. The population in the study were all children under five who experienced stunting. Respondents in this study were stunting children aged 24-59 months, living in the District of Tegalrejo. The sampling technique used was purposive sampling, with the number of samples used by 55 respondents. The data collection toolused is in the form of questionnaires. 
III. RESULT AND DISCUSSION

TABLE I. RESEARCH RESULTS

\begin{tabular}{|c|c|c|c|c|c|c|}
\hline Variable & $<-3 S D$ & Percentage & $<-2 S D$ & Percentage & Total & Percentage \\
\hline \multicolumn{7}{|l|}{ Gender } \\
\hline Male & 18 & $32.7 \%$ & 19 & $34.5 \%$ & 37 & $67.3 \%$ \\
\hline Female & 7 & $12.8 \%$ & 11 & $20 \%$ & 18 & $32,7 \%$ \\
\hline Amount & 25 & $45.5 \%$ & 30 & $54.5 \%$ & 55 & $100 \%$ \\
\hline \multicolumn{7}{|l|}{ Toddler Ages } \\
\hline 24- $<36$ month & 9 & $16.4 \%$ & 12 & $21.8 \%$ & 21 & $38,2 \%$ \\
\hline$\geq 36-<48$ month & 8 & $14.5 \%$ & 12 & $21.8 \%$ & 20 & $36,3 \%$ \\
\hline$\geq 48$ - 59 month & 8 & $14.5 \%$ & 6 & $10.9 \%$ & 14 & $25,5 \%$ \\
\hline Amount & 25 & $45.5 \%$ & 30 & $54.5 \%$ & 55 & $100 \%$ \\
\hline \multicolumn{7}{|l|}{ Birth Weight } \\
\hline$<2500$ gram & 3 & $5.45 \%$ & 4 & $7.3 \%$ & 7 & $12,7 \%$ \\
\hline 2500- 4000 gram & 22 & $40 \%$ & 26 & $47.3 \%$ & 48 & $87,3 \%$ \\
\hline Amount & 25 & $45.45 \%$ & 30 & $54.5 \%$ & 55 & $100 \%$ \\
\hline \multicolumn{7}{|l|}{$\begin{array}{l}\text { Exclusive } \\
\text { Breastfeeding }\end{array}$} \\
\hline Yes & 12 & $21.8 \%$ & 20 & $36.4 \%$ & 32 & $58,2 \%$ \\
\hline No & 13 & $23.6 \%$ & 10 & $18.2 \%$ & 23 & $42,8 \%$ \\
\hline Amount & 25 & $45.45 \%$ & 30 & $54.55 \%$ & 55 & $100 \%$ \\
\hline \multicolumn{7}{|l|}{ Social Economy } \\
\hline High & 13 & $23.6 \%$ & 9 & $16.36 \%$ & 22 & $40 \%$ \\
\hline Low & 12 & $21.8 \%$ & 11 & $20 \%$ & 33 & $60 \%$ \\
\hline Amount & 25 & $45.45 \%$ & 20 & $36.36 \%$ & 55 & $100 \%$ \\
\hline \multicolumn{7}{|l|}{$\begin{array}{l}\text { Education Level } \\
\text { of Mother }\end{array}$} \\
\hline Basic School & 7 & $12.73 \%$ & 4 & $7.27 \%$ & 11 & $20 \%$ \\
\hline Middle School & 13 & $23.64 \%$ & 20 & $36.36 \%$ & 33 & $60 \%$ \\
\hline HighSchool & 5 & $9.09 \%$ & 6 & $10.91 \%$ & 11 & $20 \%$ \\
\hline Amount & 25 & $45.45 \%$ & 30 & $54.55 \%$ & 55 & $100 \%$ \\
\hline \multicolumn{7}{|l|}{$\begin{array}{l}\text { Mother } \\
\text { Occupation }\end{array}$} \\
\hline Working & 15 & $27.27 \%$ & 7 & $12.73 \%$ & 22 & $40 \%$ \\
\hline Jobless & 11 & $20 \%$ & 18 & $32.73 \%$ & 33 & $60 \%$ \\
\hline Amount & 26 & $47.27 \%$ & 25 & $45.45 \%$ & 55 & \\
\hline \multicolumn{7}{|l|}{$\begin{array}{l}\text { Children } \\
\text { Amount } \\
\end{array}$} \\
\hline 1 & 9 & $16.36 \%$ & 13 & $23.64 \%$ & 22 & $40 \%$ \\
\hline$>=2$ & 16 & $30 \%$ & 17 & $30 \%$ & 32 & $60 \%$ \\
\hline Amount & 25 & $45.45 \%$ & 29 & $52.73 \%$ & 54 & $100 \%$ \\
\hline
\end{tabular}

Based on Table 1, the number of boys under five who experienced stunting was 37 children with $18(32.7 \%)$ with a value of <-3SD and $19(34.5 \%)$ with <-2SD. While the number of stunting girls was 18 children with 7 (12.8\%) -3SD and $11(20 \%)$ with values <-2SD. Boys and girls had the same chance of stunting with $\mathrm{OR}=1.03 \mathrm{CI} 95 \%$ between $1.18-1.75$ 
[8]. The other research state that male sex is at 4 times higher risk of being stunted than girls [9]. But it is in contrast with the other of the last research stated that girls had a smaller chance of experiencing stunting ( $\mathrm{AOR}=0.72,95 \% \mathrm{CI}$ : 0.58 - 0.90; $\mathrm{p}=0.005)$ [10].

Based on Table 1, the most stunting children aged 24-36 months were 21 children with the highest proportion of <2 SD (12 children). Stunting children aged $\geq 36$ months -48 months numbered 20 , and children aged $\geq$ children. Children aged 2-3 years have a risk of experiencing stunting of 1.64 times more significant 95\% CI (1.22-2.21) [11]. The results of the study mentioned that the risk of stunting increases when the child is $>24$ months. This is because at the age of $>2$ years the child has begun to be weaned / does not get adequate breast milk intake.Moreover the children are more exposed to contaminated food so that the feeding is not in accordance with the children's need can cause children to experience malnutrition [9].

Based on table 1, most of the birth weight of respondents born with 2500-4000gram body weight were 48 children with a percentage of $47.3 \%$ of children with a value of $\angle-2$ SD and $40 \%$ of children with $<-3$ SD. This study means that low birth weight is not contributing a length of body. Its similar with the last research that there was no relationship between LBW status and the incidence of stunting in children under five in both rural and urban areas [12]. But the other studies stated that children born with low birth weight have is associated with the incidence of stunting [13] [9] and had a risk of stunting 1.8 times with $95 \%$ CI (1.17-2.4) [11].

Based on table 1, respondents who were given exclusive breastfeeding were $32(48.2 \%)$, while the remaining 33 respondents $(51.8 \%)$ were not given exclusive breastfeeding. According to last research the risk of stunting can be reduced if children get exclusive breastfeeding and MP-ASI according to their needs [12]. Babies who are given exclusive breastfeeding have a stronger immune system than babies who are not given exclusive breastfeeding. Infants aged $>6$ months given MPASI according to their needs also reduce the risk of stunting. The last research states that from a total of 1366 respondents aged 0-23 months, $54.1 \%$ were given exclusive breastfeeding and were stunted, this can be concluded that there was no relationship between exclusive breastfeeding and the incidence of stunting [14].

Based on table 1, the majority of respondents or $49(89 \%)$ people have a regular eating pattern in which they eat approximately 2-3 times/day, as well as getting used to breakfast, while $11 \%$ (6 respondents) do not have a regular eating pattern. Knowledge of parents, especially mothers in child feeding, is very important because it will affect the practice of feeding. Poor feeding practices such as irregular eating patterns, poor nutrition, inadequate feeding during illness, inadequate amounts of food and poor nutritional content are risk factors for stunting [15]. Food diversity also affects the types of nutrients absorbed by the body. Food diversity affects the kinds of nutrients absorbed by the body, the more the kinds of food consumed by children will further reduce the risk of malnutrition, one of which is stunting. Feeding that is not age-appropriate will increase the risk of stunting [16]. Children who are fed according to their needs have a chance of $24.2 \%$ experiencing stunting, while children who are not given food according to their needs are at risk $31.3 \%$ have stunting [14]. Besides, giving mineral micronutrients can increase the frequency of eating per day and improve the nutritional status of children (Candra, 2017).

Based on table 1, $33(60 \%)$ respondents came from families with monthly income <UMK Yogyakarta. It is supported by the last research which states that families with low-income increase the risk of stunting by 1,35 times greater $\mathrm{OR}=1.35,95 \%$ CI 1.12-1.66 [8]. But this study reveals from the other study that there is a significant relationship between family income and the incidence of stunting in children under five in both rural and urban areas [12]. Low family income will affect the ability of families to meet the nutritional needs of children, thereby increasing the risk of stunting. Other research conducted in India and Guatemala states that the lower the socioeconomic level of the family, the higher the risk of stunting with p-value $=<0,0001$ OR 3.36 (India) and p-value: $=<0,0001$ OR 8.35 (Guatemala) [17]. But the other study states that the level of the socioeconomic family does not affect the incidence of stunting [18].

Majority of mothers' education is in the Middle School (Senior High School) with 33 respondents (60\%), 11 mothers with primary education (20\%), and 11 mothers graduated from tertiary education (20\%). The mother's education level affects their parenting in children. Uneducated mothers increase the risk of stunting by 1.3 times $(\mathrm{OR})=1.27,95 \%$ confidence interval (CI) 1.11-1.61 (Syed et al., 2003). Research (Manggala et al., 2018) reports that low maternal education increases the risk of stunting by 2.53 times $(\mathrm{CI}=$ $2.12-5.52) \mathrm{p}$-value $=0.013$. The mother's education level has a significant effect on the incidence of stunting [12]. But it is not similar with the other study which states that mothers who received less than nine years of education / did not complete primary education increase the risk of stunting by 2.6 times more $(\mathrm{RR}=2.60,95 \% \mathrm{IK}=1,23-5.46 ; \mathrm{p}=0.02)$ [19].

The majority of mothers who do not work/are housewives are $33(60 \% \%)$, and as many as 22 mothers (40\%) work outside the house. In Jakarta, the mother's work does not influence the incidence of stunting [19]. Mothers who work outside the house or who do not work do not affect the incidence of stunting [9], Another study states that the mother's work affects the occurrence of cases of malnutrition in children, children having mothers who are still studying / school are at greater risk of stunting after the age of 3 years, while children having working mothers are at higher risk of overweight, this is because the child gets more food intake because families have better financial abilities [20].

The majority of respondents are not the first child / do not have siblings $32(58.2 \%)$ children are the second child / or third child. While $22(41.8 \%)$ are the first children. The sequence of childbirths does not affect the incidence of stunting; both the first, second, and third and fourth children do not affect the risk of stunting [19] [18]. But there is a research that the incidence of stunting is statistically related to the presence of 2 toddlers in one house [9]. The greater the number of children, the higher the risk of stunting. This is due to the less intake and diversity of food received by children for families with low socioeconomic[20]. 


\section{CONCLUSION}

The findings of this research were the characteristics of stunting toddlers (the standard deviations of stunting toddlers was <-3SD), stunting is more common in male toddlers, under three years of age, having normal birth weight, history of being given exclusive breastfeeding, regular eating patterns, and toddlers not single children., come from families with an income above MSE, middle-educated mothers and mothers not working.

\section{ACKNOWLEDGMENT}

This research was supported by Indonesian Ministry of Research, Technology and Higher Education

\section{REFERENCES}

[1] MCA Indonesia "Stunting dan Masa Depan Indonesia," Millenn. Chall. Acc. - Indones., vol. 2010, pp. 2-5, 2013.

[2] Kemenkes RI, "Laporan Nasional Riskesdas 2018." Lembaga Penerbit Badan Penelitian dan Pengambembangan Kesehatan, Jakarta, 2019.

[3] Mentri Kesehatan RI, "Riset Kesehatan Dasar 2018," 2018.

[4] Dinkes Diy, "Profil Kesehatan Daerah Istimewa Yogyakarta Tahun 2018," 2019

[5] Fitri Kueharisupeni, "Berat Lahir Sbg Faktor Dominan Stunting Pada Balita (12-59 Bulan) Di Sumatera (RKD, 2010)," 2012.

[6] N. Siahaan, Z. Lubis, and F. Ardiani, "Faktor-faktor yang Berhubungan dengan Kejadian Stunting pada Balita di Wilayah Kerja Puskesmas Tanjung Tiram, Kecamatan Tanjung Tiram, Kabupaten Batu Bara Tahun 2013," J. Gizi, Kesehat. Reproduksi, dan Epidemiol., vol. 1, no. 1, pp. 1-5, 2014.

[7] I. Picauly and S. M. Toy, "Analisis Determinan Dan Pengaruh Stunting Terhadap Prestasi Belajar Anak Sekolah Di Kupang Dan Sumba Timur NTT," J. Gizi dan Pangan, vol. 8, no. 1, p. 55, 2013.

[8] S. M. Syed, S. BJ, L. S, M. A, and B. R., "Prevalence and correlates of stunting among children in rural Pakistan," Pediatr. Int. Off. J. Japan Pediatr. Soc., vol. 45, no. 1, pp. 49-53, 2003.

[9] L. M. García Cruz, G. González Azpeitia, D. Reyes Súarez, A. Santana Rodríguez, J. F. Loro Ferrer, and L. Serra-Majem, "Factors associated with stunting among children aged 0 to 59 months from the central region of Mozambique," Nutrients, vol. 9 , no. 5, pp. 1-16, 2017.
[10] Ramli, K. E. Agho, K. J. Inder, S. J. Bowe, J. Jacobs, and M. J. Dibley, "Prevalence and risk factors for stunting and severe stunting among under-fives in North Maluku province of Indonesia," BMC Pediatr., vol. 9, p. 64, 2009.

[11] A. El Taguri et al., "Risk factors for stunting among under-fives in Libya," Public Health Nutr., vol. 12, no. 8, pp. 1141-1149, 2015.

[12] F. O. Aridiyah, N. Rohmawati, and M. Ririanty, "Faktor-faktor yang Mempengaruhi Kejadian Stunting pada Anak Balita di Wilayah Pedesaan dan Perkotaan (The Factors Affecting Stunting on Toddlers in Rural and Urban Areas)," e-Jurnal Pustaka Kesehat., vol. 3, no. 1, pp. 163-170, 2015.

[13] C. N. Rachmi, K. E. Agho, M. Li, and L. A. Baur, "Stunting, underweight and overweight in children aged 2.0-4.9 years in Indonesia: Prevalence trends and associated risk factors," PLoS One, vol. 11, no. 5, pp. 1-17, 2016.

[14] H. Torlesse, A. A. Cronin, S. K. Sebayang, and R. Nandy, "Determinants of stunting in Indonesian children: Evidence from a cross-sectional survey indicate a prominent role for the water, sanitation and hygiene sector in stunting reduction," BMC Public Health, vol. 16, no. 1, pp. 1-11, 2016.

[15] T. Beal, A. Tumilowicz, A. Sutrisna, D. Izwardy, and L. M. Neufeld, "A review of child stunting determinants in Indonesia," Matern. Child Nutr., vol. 14, no. 4, pp. 1-10, 2018.

[16] J. H. Rah et al., "Low dietary diversity is a predictor of child stunting in rural Bangladesh," Eur. J. Clin. Nutr., vol. 64, no. 12, pp. 1393-1398, 2010.

[17] R. Martorell and M. F. Young, "Patterns of Stunting and Wasting: Potential Explanatory Factors 1 - 3," Am. Soc. Nutr., vol. 3, pp. 227-233, 2012.

[18] A. K. Manggala, K. W. M. Kenwa, M. M. L. Kenwa, A. A. G. D. P. J. Sakti, and A. A. S. Sawitri, "Risk factors of stunting in children aged 24-59 months," Paediatr. Indones., vol. 58, no. 5, pp. 205-12, 2018.

[19] H. Gunardi et al., "Association between parental sociodemographic factors and declined linear growth of young children in Jakarta," Med. J. Indones., vol. 26, no. 4, pp. 286-292, 2017.

[20] S. Keino, G. Plasqui, G. Ettyang, and B. Van Den Borne, "Determinants of stunting and overweight among young children and adolescents in sub-Saharan Africa," Food Nutr. Bull., vol. 35, no. 2 , pp. $167-178,2014$ 